\title{
Spare the Rod, Spoil the Society? The Moral Complexity of Caning in Singapore
}

\author{
Hannah Sorenson \\ St. Olaf College \\ Hannah.k.sorenson@gmail.com
}

\begin{abstract}
You have the opportunity to decide whether or not a person gets caned, the only caveat is that they have committed a crime against you. What will you do? This essay explores the moral complexity of caning in Singapore through an exploration of corporal punishment, criminal justice, moral philosophy, and the Asian values debate; a dilemma that ultimately places concerns of society and the individual at odds. In doing so, the essay argues that the morality of caning changes on the basis of the ethical framework and modification of situation variables. Even so, the moral complexity of caning is not superficially evident. In order to thoroughly engage with all elements of this complexity, this essay begins by attempting to decipher the place of punishment within international human rights frameworks. From there, the essay explores the morality of punishment and its employ in colonial endeavors. This leads to a discussion of modernization, humanitarian ideologies, and control. By creating a framework for analyzing criminal justice in Singapore-including an outline of the intersections of criminal justice, development, and prosperity - this essay seeks to explore the balance between corporal punishment as a tool of prosperity and corporal punishment as a source of pain and degradation. When placed in consequentialist and virtue-based ethical frameworks caning in Singapore looks very different, forcing the moral actor to weigh societal concerns with concerns for individual pain, suffering, and liberties.
\end{abstract}

Keywords: Caning, Morality, Society, Punishment.

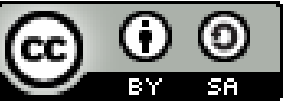

Copyright $\odot 2021$ by Author(s)

This work is licensed under a Creative Commons Attribution-ShareAlike 4.0 International License. All writings published in this journal are personal views of the authors and do not represent the views of this journal and the author's affiliated institutions.

\section{HOW TO CITE:}

Sorenson, Hannah. "Spare the Rod, Spoil the Society? The Moral Complexity of Caning in Singapore" (2021) l:1 Contemporary Sociological Issues 34-54.

$\begin{array}{llll}\text { Submitted } & \text { :October 20, } 2020 & \text { Accepted } & \text { :January 2, 2021 } \\ \text { Revised } & \text { :November 24, 2020 } & \text { Publish } & \text { :February 5, 2021 }\end{array}$




\section{INTRODUCTION}

Consider the following scenario. You are a middle class Singaporean citizen. A crime was committed against you - a home burglary - with ample evidence to press charges against the offender, your neighbors' sixteen year-old son. The crime has impacted your security, your finances, and greatly inconvenienced you. Under Singaporean criminal law, men convicted of crimes and deemed of good health will endure a mandatory caning in addition to any prison sentence. The minimum required punishment for robbery is twelve strokes of the cane. Should you report the crime, given the great impact it has had on your life and security? Or, knowing punishment will result in the boy's physical and mental traumatization, should you avoid reporting the crime?

What would encourage you to report the crime? Many of the crimes for which caning is prescribed involve serious harm, generally physical, to the victim ${ }^{1}$ Some may argue that caning is a proportional punishment, countering the harm caused to the victim by physically inscribing the criminal's wrongful acts. So, too, has it been argued that the deterrent effect of caning is central to the preservation of Singaporean success; along the same lines, some claim that the top-down authoritative approach to punishment and aversion to crime are embedded in the Confucian ethics that heavily influence Singaporean culture $^{2}$.

On the other hand, what might encourage you to abstain from reporting? Humanitarian values, particularly those espoused by the Universal Declaration of Human Rights (UDHR), may lead you to believe that caning is an excessive form of punishment, bordering on torture 3 . Some argue that the act of caning itself is dehumanizing, and the pain it involves cannot be viewed solely as a deterrent for punishment ${ }^{4}$. Inequalities in the qualifications for caning-who is caned and who is not-may lead you to view the punishment as fundamentally flawed on the basis of equality; otherwise, one may view it as an outdated, backward cultural relic ${ }^{5}$.

All of these arguments are valid. Even so, we must delve deeper into the issue of caning in order to understand the complexities upon which it rests. While I am in no position to definitively declare caning as normatively "right" or "wrong," I argue that

\footnotetext{
${ }^{1}$ Zachary Reynolds, "Intertwining Public Morality, Prosecutorial Discretion, and Punishment : Low Crime and Convictions in Singapore," University of Chicago Law School, 2017, 48.

${ }^{2}$ Kishore Mahbubani, Can Asians Think? (Singapore: Time Books International, 1998), https://www.goodreads.com/work/best_book/342440-can-asians-think; Reynolds, "Intertwining Public Morality, Prosecutorial Discretion, and Punishment : Low Crime and Convictions in Singapore." 3 "Statistical Update 2018 | Human Development Reports," UNITED NATIONS DEVELOPMENT PROGRAMME Human Development Reports, 2018, http://hdr.undp.org/en/content/human-developmentindices-indicators-2018-statistical-update.

${ }^{4}$ Steven Pierce, Punishment and the Political Body: Flogging and Colonialism in Northern Nigeria, Discipline and the Other Body (Duke University Press, 2006), https://doi.org/10.1515/9780822387930-008.

${ }^{5}$ Selena Lum, "Caning of Prisoners is Constitutional, Court of Appeal Rules." The Straits Times," 5 Maret 2015, https://search-proquest-com.ezproxy.stolaf.edu/docview/1660636165 ?accountid=351.
} 
corporal punishment in Singapore lies somewhere in between, and the extent to which it aligns with "right" or "wrong" varies on the basis of ethical framework. By exploring this dilemma, we will see that the complexity of caning places societal concerns at odds with individual liberties. Later on, in this essay, I will apply scalar expectable consequentialism in support of reporting and an agent-based approach to virtue ethics in support of abstaining. Similarly, I argue that exploring the connections between moral philosophy, criminal justice, and the Asian values argument is essential to thoroughly exploring the complexities of caning in modern Singapore.

I would like to emphasize that my argument is rooted in meta-ethical relativism, which contends that moral judgements are not absolutely "true" or "false." Instead, moral judgements are only "true" or "false" relative to certain ethical frameworks 6 . While it is my personal belief that caning is a violation of human rights, this paper is a challenge to my own beliefs and the ease by which personal moral claims are made. This paper also challenges the dominant role played by consequentialist ethics in American society when discussing human rights violations, and should therefore be considered a critical reflection on the complexity of human rights violations. Meta-ethical relativism will serve as the foundation of this critical reflection, as well as the application of consequentialism and virtue ethics to the moral dilemma of caning in Singapore.

I begin my argument by discussing the relationship between human rights and punishment; where does it all fit together? Next, I explore the relationship between morality and punishment in order to understand the philosophical frameworks used by scholars and states alike to justify punishment. As caning was an import of British rule in Singapore, I explore corporal punishment in the colonial context, so as to understand the complicated history from which caning in Singapore has progressed. Exploring colonization illuminates how national history affects our victim, as well as how pain and dehumanization affect our offender. From this point, the paper engages directly with the case of Singapore, examining Singapore's criminal justice system, the relationship between criminal justice and development, and the Asian values debate. At this point, I argue that Singapore's current development status renders development-based defenses of caning inapplicable. I also argue that Singapore criminal justice should be viewed as a repertoire of norms which can change over time without becoming invalid. This is followed by the application of moral frameworks to the two potential outcomes of the above-presented moral dilemma and a concluding discussion.

It is important at this point to clarify a few terms that I will use throughout this essay. First and foremost, as one may have noticed in the dilemma text, I substitute the word "offender" for the word "perpetrator." This is not an attempt to sway one's conscience, but rather an effort to step away from the connotations and weighted meaning

\footnotetext{
${ }^{6}$ Emrys. n.d Westacott, "Moral Relativism," The Internet Encyclopedia of Philosophy (blog), diakses 27 November 2018, https:/iep.utm.edu/moral-re/.
} 
of "perpetrator." Similarly, at times I substitute "the offended" for "victim," however the term "victim" does appear due to the language of the scholars with whom I engage. Throughout this essay I also use "corporal punishment" interchangeably with "caning." The words are not inherently synonymous; however, in the case of Singapore, they share one meaning. In the section on colonization and corporal punishment, I use the term "flogging," which can be a synonym for caning, yet in this context refers to the use of a different tool and a slightly different practice.

\section{LITERATURE REVIEW}

This essay will engage with myriad disciplines in order to gain a clearer picture of corporal punishment through conversations on criminal justice, moral philosophy, and "Asian values." Each of these three components informs and enriches the conversations of the others, in many ways unexpected by this author. Human rights' interest in corporal punishment is not new, though it was reinvigorated with regard to Singapore by the highly politicized 1994 caning of American teenager Michael Fay. ${ }^{7}$ This sparked a wider debate on the compatibility of Asian and Western values, leaving a rich body of literature in the fields of philosophy, political science, and criminal justice, which attempts to decipher what precisely Asian values are, their universality, and the universality of values such as human rights. An abundance of literature also speaks to the moral ambiguity of corporal punishment, the relationship between criminal justice and development, and the benefits of a diversified criminal justice system in Singapore. As Singapore continues to move forward as a global player, exploring the societal role of corporal punishment, the philosophical justifications for and arguments against it, and the universality of Asian values will prove fruitful in a wider scheme of mutual respect and understanding within international society.

Joining the conversation on corporal punishment as a human right, I rely upon the Universal Declaration of Human Rights (UDHR) and United Nations Convention against Torture and Other Cruel, Inhuman, or Degrading Treatment or Punishment (UNCAT) to provide surface level definitions for torture and lawful sanctions. World Corporal Punishment Research is a non-profit, factual website devoted to objective research of corporal punishment and tracing connections with broader social, political, and historical contexts. It is referenced in other scholarship as a very detailed source of information on corporal punishment in Singapore. Another formative source was the historical-anthropological exploration of discipline, punishment, and colonialism put forth by Discipline and the Other

\footnotetext{
${ }^{7}$ In 1994, American teenager Michael Fay was sentenced to caning as a result of conviction under Singapore's 1966 vandalism law. The sentence garnered intense international attention and criticism, including pleas from then-president Bill Clinton for amnesty (Rajah 2011). In response, Lee Kuan Yew and other Singaporean officials argued for the punishment within the Asian values framework. Michael Fay was eventually caned, and upon his release from prison returned to the United States, where he has lived since then (citation pending).
} 
Body ${ }^{8}$, a collection of essays edited by Steven Pierce and Anupama Rao. Pierce, faculty of history at the University of Manchester, and Rao, professor of history at Barnard College, are both historical anthropologists whose essays on flogging in Northern Nigeria and torture in colonial India, respectively, deeply inform my discussion of the complex relationship between power, modernization, human rights, and the corporeal.

In the conversation of moral and punitive philosophy, I rely upon the contributions of scholars to the Internet Encyclopedia of Philosophy (IEP). IEP is a public collection of peer-reviewed scholarship on key philosophical frameworks and authors (IEP, n.d.). The entries on punishment, virtue ethics, and consequentialism prove particularly useful for this paper because they provide nuanced moral frameworks from which to view my dilemma. Additionally, the philosophical contemplations of Herbert Morris, a professor of law and philosophy at the University of California Los Angeles, critically contemplates the rights associated with punishment; namely, the right to be punished ${ }^{9}$. Morris is a renowned scholar of moral and legal philosophy. His works enable this essay to consider a very complex dynamic between the moral philosophy of punishment and human rights.

Applying moral frameworks to corporal punishment in Singapore requires a detailed understanding of criminal justice in Singapore. I include numerous publications from the faculty of law at National University Singapore, which was for a long time the only faculty of law in the country. Of these publications, three are written by Kumaralingam Amirthalingam, whose research focuses primarily on criminal law and justice. "Criminal Justice and Diversionary Programmes in Singapore"10 is an imperative source, as it provides both a detailed summary of recent changes in Singaporean criminal justice and the social context of these changes, as well as scholarly reflection on the purpose of review and change in a system of criminal justice. This article clearly articulates that Singapore should be and, to some extent, is open to change; the harsh punishment of the past is something to be reviewed as a component of Singapore's crucial development era. Similarly, Amirthalingam's "Importance of Criminal Law"ll reflects upon Singapore's criminal law strategy in education and application, situated in the context of modern Singapore's prosperity and stability. Also faculty of law at National University Singapore, Wing-Cheong Chan details restorative juvenile justice in "Family Conferencing for Juvenile Offenders"12, which was first implemented in 1997. Chan's reflection on changes to

\footnotetext{
${ }^{8}$ Anupama Rao dkk., Discipline and the Other Body: Correction, Corporeality, Colonialism (Durham: Duke University Press, 2006), https://muse.jhu.edu/book/71094.

${ }^{9}$ Herbert Morris, "PERSONS AND PUNISHMENT," The Monist 52, no. 4 (1968): 475-501.

${ }^{10}$ Kumaralingam Amirthalingam, "Criminal Justice and Diversionary Programmes in Singapore," Criminal Law Forum 24, no. 4 (1 Desember 2013): 527-59, https://doi.org/10.1007/s10609-013-9216-6.

${ }^{11}$ Kumaralingam Amirthalingam, "THE IMPORTANCE OF CRIMINAL LAW," Singapore Journal of Legal Studies, 2017, 318-28.

${ }^{12}$ Wing-Cheong Chan, "Family Conferencing for Juvenile Offenders: A Singaporean Case Study in Restorative Justice," Asian Journal of Criminology 8, no. 1 (1 Maret 2013): 1-23, https://doi.org/10.1007/s11417-0119122-y.
} 
Singaporean juvenile justice calls for a justice system focused on the experiences of the people involved-perpetrator, victim, and their families-before the crime itself. Additionally, Zachary Reynolds' "Intertwining Public Morality, Prosecutorial Discretion, and Punishment: Low Crime and Convictions in Singapore"13 directly connects criminal justice practices and the Asian values argument, specifically the role of Confucian ethics in community policing and low crime rates ${ }^{14}$. Altogether, these publications provide a detailed image of multifaceted criminal justice in Singapore; nestled within this context rests the practice of caning.

Caning in Singapore cannot be discussed without reviewing the Asian values debate. My engagement with this conversation begins with Jothie Rajah, full time appointee of the American Bar Foundation, who conducted a rhetorical analysis of Lee Kuan Yew's Asian values arguments in the nineties as a part of a wider exploration of authoritarianism and rule of law in Singapore. From Rajah's analysis, I turn an ear to Kishore Mahbubani, former diplomat and chair of the Lee Kuan Yew School of Public Policy at National University Singapore. Mahbubani is author of countless publications on the topic of relationships between the East and the West. In particular, the essays "Can Asians Think"15 "An Asian Perspective on Human Rights and Freedom of the Press" (1993), "The West and the Rest" (1992), "Singapore: Recipes for a Crowded Planet" (1998), and "The Case Against the West: America and Europe in the Asian Century" (2008)16 all expound the Asian values argument in a social and political context. Furthermore, two texts guide my engagement in critical thinking with regard to the Asian values debate: Sally Engle Merry's Human Rights e Gender Violence ${ }^{17}$ and Wm. Theodore de Bary's Nobility e Civility $^{18}$. These texts each explore very dynamic concepts-culture and virtue, respectively - with respect to their multiplex, transformative properties. As a result, this paper is able to clearly consider arguments for and against the compatibility of Asian values with human rights law, and to place punishment in this context without prolonging ignorance or limiting the complexity of moral philosophy.

\footnotetext{
${ }^{13}$ Reynolds, "Intertwining Public Morality, Prosecutorial Discretion, and Punishment : Low Crime and Convictions in Singapore."

${ }^{14}$ Reynolds.

${ }^{15}$ Mahbubani, Can Asians Think?

${ }^{16}$ Kishore Mahbubani, "The Case against the West: America and Europe in the Asian Century," Foreign Affairs 87, no. 3 (2008): 1ll-24.

${ }_{17}$ Susan Engle Merry, Human Rights and Gender Violence (Chicago: University of Chicago Press, 2006), https:/press.uchicago.edu/ucp/books/book/chicago/H/bo3636543.html.

${ }^{18}$ William Theodore De Bary, NOBILITY AND CIVILITY (Cambridge: Harvard University Press, 2004).
} 


\section{HUMAN RIGHTS AND PUNISHMENT}

Where does caning, or punishment for that matter, fit in the scheme of human rights? International society has made a concerted effort to define and condemn torture and excessive punishment. UDHR directly addresses punishment, torture, justice, and rule of law multiple times. The most applicable of these rights to caning and practices of punishment at large is Article V, which reads, "no one shall be subjected to torture or to cruel, inhuman or degrading treatment or punishment"19. Article V is the foundation for the 1987 Convention against Torture and Other Cruel, Inhuman or Degrading Treatment or Punishment (UNCAT). UNCAT's definition of torture conveys the complexity of corporal punishment, stating that any infliction of "severe pain or suffering" for the purpose of punishing an individual qualifies as torture, yet does not include pain or suffering "from, inherent in, or incidental to, lawful sanctions"20. Put differently, the legal infliction of pain, such as that inherent in corporal punishment, is permissible under UNCAT. Singapore has neither signed nor ratified this convention; even so, it is clear that within UNCAT the parameters of torture remain ambiguous. Failure to delineate between lawful pain and excessive punishment-which cannot be easily defined without challenging state sovereignty-amplifies the ambiguity of UDHR and UNCAT. While it is unlikely that international society's definitions of torture will shape our victim's decision, they are essential to understanding why corporal punishment is labelled as a human rights violation in the first place.

Caning undoubtedly involves a great deal of pain. Historian and anthropologist Steven Pierce argues that the utter inexpressibility of pain, such that it can only be articulate through cries or analogies, makes it a private experience that cannot be otherwise explained or excused ${ }^{21}$. The pain experienced during caning is compounded, in the Singaporean context, by the fact that the prisoner must be naked. Strapped by the ankles and wrists to a broadsided A-frame, prisoners may experience shame and degradation as a result of the physical organization of caning (Figure 1). For these reasons, the abstract experience and presence of pain must be considered in determining the morality of corporal punishment; here we can see the emergence of a case for corporal punishment as a human rights violation.

Pain does not end with the final stroke of the cane. In recent years, many have reported a splitting of the flesh followed by bleeding. Although prisoners with open wounds are treated with antiseptic, and in some cases bandages, they must wait for the

\footnotetext{
19 "United Nations Human Rights Office of the High Commissioner: Convention against Torture and Other Cruel, Inhuman or Degrading Treatment or Punishment," UNITED NATIONS HUMAN RIGHTS, diakses 9 Oktober 2018, https://www.ohchr.org/en/professionalinterest/pages/cat.aspx.

20 "United Nations Human Rights Office of the High Commissioner: Convention against Torture and Other Cruel, Inhuman or Degrading Treatment or Punishment."

${ }^{21}$ Pierce, Punishment and the Political Body.
} 
wounds to heal (World Corporal Punishment Research, n.d.). In the meantime, prisoners may not be able to wear shorts and face grave difficulty using the bathroom or sitting, lest their wounds reopen. The magnitude of pain from initial injury alone can result in difficulty sleeping, which can have wider implications for the prisoner's physical and mental health (World Corporal Punishment Research, n.d.). In the context of human rights, the prolonged suffering involved in corporal punishment and the dehumanization that is accompanied by the process of caning could indeed be considered excessive and degrading, further blurring the clear line-so to speak-between lawful sanctions and torture delineated by international law. In fact, caning begins to look a lot like torture.

Figure 1 (World Corporal Punishment, n.d.)

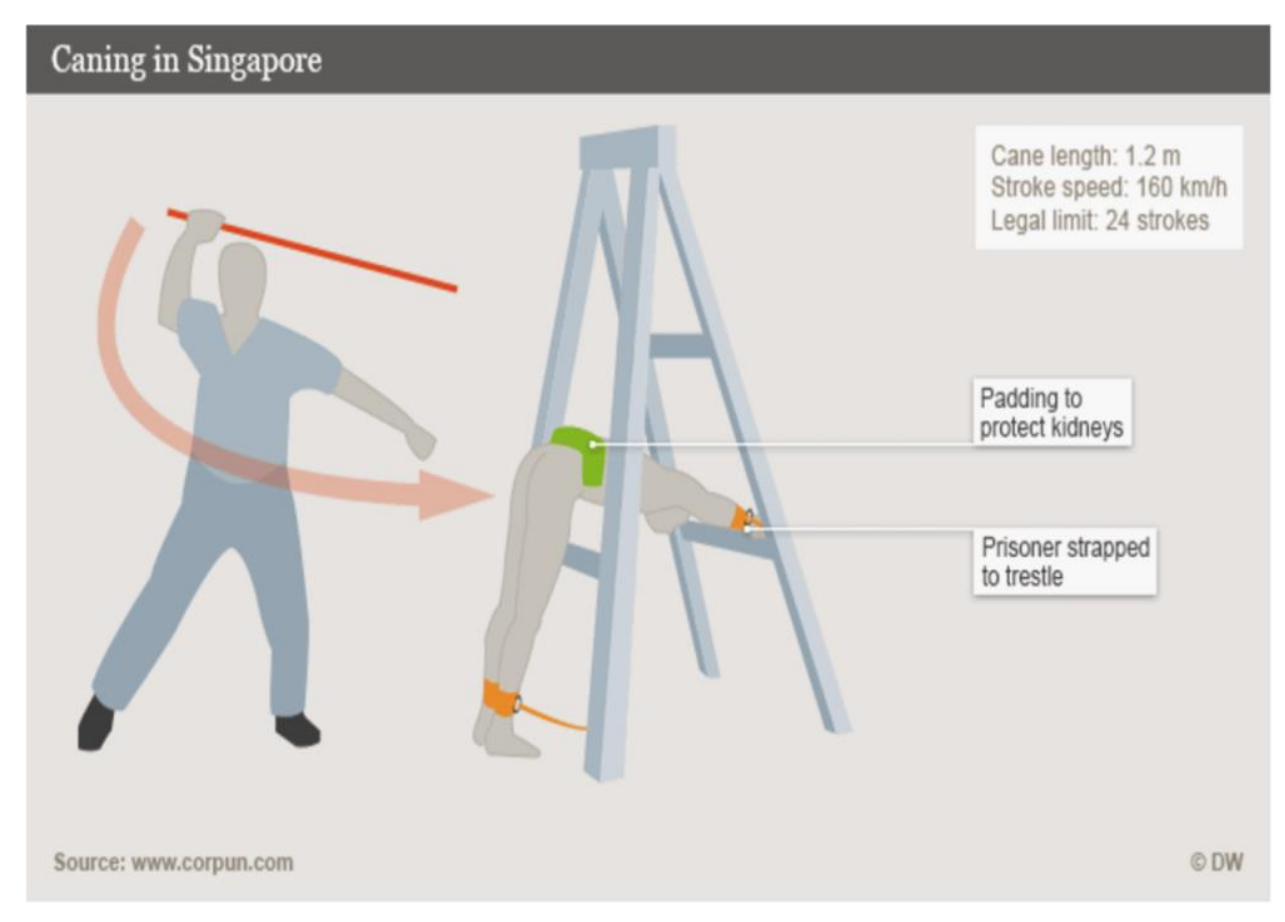

Source: www.corpun.com

The relationship between human rights and punishment does not begin and end with caning. Herbert Morris argues that in addition to the natural, inalienable right to freedom, humans have a right to be punished derived from the fundamental human right to be treated as a person ${ }^{22}$. This right is unique in that the right to be treated as a human cannot be waived on the basis of age or other factors. It is absolute in that rights exist regardless of whether or not a person is accorded them. Morris' rights framework rests on the idea that there are two alternative systems of punishment: a system of institutions

${ }^{22}$ Morris, "PERSONS AND PUNISHMENT." 
involving pain and suffering, and a system of therapies, the former being more predictable and less dehumanizing than the latter ${ }^{23}$. As a result, punishment is rooted in not only a right to be treated as a person, but also the guarantee of equal dignity and rights articulated by UDHR. Although the United Nations does not acknowledge a right to be punished in either UDHR or UNCAT, the unclear bound between punishment and torture - only barely touched upon by the idea of lawful pain, which is itself vagueenables a variety of punishments that border on excessive while providing no mechanism to enforce standards of torture and appropriate punishment.

The relationship between human rights and punishment is further complicated by the idea that decisions on punishment are social decisions and therefore demand mutual respect and some immunity or distance from human rights doctrine. Kishore Mahbubani argues that no social decision is "intrinsically superior;" just as the United States has elected "habitual crime" to be an acceptable price for maintenance of personal liberties, so has Singapore placed the desire for security before "rigorous due process"24. For Mahbubani, security refers to a level of stability necessary for economic development; political instability and rampant crime may deter foreign direct investment, hampering the state's ability to prosper economically ${ }^{25}$. The argument for distance is part of a wider critique of Western developmental expectations, in which Mahbubani argues that democracy and human rights cannot realistically precede economic development; rather, development must come first ${ }^{26}$. In Mahbubani's view, this social decision is the sovereign decision of the state, which, in Singapore's case, chose to use corporal punishment as a way to discourage crime and present the country as a politically, socially stable state with profitable investment opportunities. Were Singapore a representative-democracy, as Mahbubani infers, the government's decision would be rooted in wider society's social values ${ }^{27}$. By his logic, punishment is shifted from an international, human rights framework to a local, domestic decision-making context. At the same time, punishment moves to a social sphere in which power is shifted from the state to the society; no longer can we so easily say that corporal punishment is torture. In a local context, the universal values of UDHR conflict with domestic decisions and values, as can be seen in the Asian values debate. Later on, we will see how a specific definition of culture can combat the universal versus local values challenge. Realistically, the degree to which Singapore's government actually reflects social values is debatable. While Singapore self-identifies as a democracy, the People's Action Party has maintained control for the duration of the state's modern

\footnotetext{
${ }^{23}$ Morris.

${ }^{24}$ Mahbubani, "The Case against the West."

${ }^{25}$ Amirthalingam, "Criminal Justice and Diversionary Programmes in Singapore"; Mahbubani, Can Asians

Think?; Reynolds, "Intertwining Public Morality, Prosecutorial Discretion, and Punishment : Low Crime and Convictions in Singapore."

${ }^{26}$ Mahbubani, Can Asians Think?

${ }^{27}$ Mahbubani.
} 
political era. It is unclear to what extent our victim feels represented by their government; however, the state's educational emphasis on national identity contributes to the prevalence of culture- and values-based claims ${ }^{28}$.

\section{MORAL PHILOSOPHIES OF PUNISHMENT}

Physical injury certainly fits into a particular philosophy of punishment. That being said, the presence of pain is not inherent to all theories of punishment. Retributivist punishment theory would suggest that punishment be proportional, so as to balance just desserts (Murtagh, n.d.). The clearest example is capital punishment in response to a murder conviction: pay for one life with another. When considering crimes that do not involve a loss of life, it becomes harder conceive of what an appropriate punishment may be. Take, for example, vandalizing public property, a crime for which caning is applicable in Singapore. Should an offender repair the property they have vandalized? Should they spend time in jail? Perhaps caning would be better. Three strokes or four? While it may be easy to decide what is disproportionate-in this case, we may argue that the death penalty is excessive-it is challenging to define what a proportional punishment should be. Regarding our dilemma, I argue that retributivism is not conducive to a concise examination of caning in Singapore. The punishment for robbery is already decided: a minimum of twelve strokes of the cane ${ }^{29}$. In order to validate or refute the morality of caning through retributivism, we would need to understand how each stroke of the cane is weighted. To do so would be a tedious effort and would likely not reflect the ethical framework - however subtle-driving the decision of our victim.

Consequentialism is a school of ethical reasoning and philosophy that pictures humans as benefit-maximizers. Humans experience the world through pleasure and pain, and throughout the process seek to maximize pleasure (Murtagh, n.d.). Human behavior and decisions have implications for wider communities; something undoubtedly true about criminal justice. In the context of punishment, consequentialism would suggest that justice and moral "good" is achieved when benefit is maximized (Murtagh, n.d.). A murderer should not be put to death on the basis of a deontological commitment to justice; rather, they should face punishment that will deter themselves and others from committing such an act again. Throughout this process, consequentialist reasoning also takes into account the wider community connected to both the offender and the offended. One of the greatest benefits of punishment is deterrence, and as a result, consequentialist punishment theory is deeply committed to the deterrent effect of punitive action.

\footnotetext{
${ }^{28}$ Susan A Adler, "Educating Citizens: A Cross-Cultural Conversation," Journal of International Social Studies 1, no. 2 (2011): 2-20.

${ }^{29}$ Reynolds, "Intertwining Public Morality, Prosecutorial Discretion, and Punishment : Low Crime and Convictions in Singapore."
} 
A critique of consequentialist punishment theory is the potential to forego what Immanuel Kant called the categorical imperative (Murtagh, n.d.). Essentially, the prioritization of benefit maximization, and thereby deterrence, inherent in consequentialist reasoning legitimates the use of a person as a means to an end. It is by no means certain that consequentialist reasoning always will or does result in such a practice; however, it could enable acts that would otherwise be deemed unquestionably morally "wrong." For example, if the arrest of an innocent person would bring an end rioting, it would be morally permissible as a result of benefit maximization (Murtagh, n.d.). I would like to emphasize again that this is not an innate part of consequentialist punishment theory; in fact, consequentialism is at the heart of many humanitarian reforms, as can be seen in the prison reform efforts of famed utilitarian Jeremy Bentham (Murtagh, n.d.). It also compels actors to consider the effects conviction or any harsher form of punishment will have on the offender and their loved ones ${ }^{30}$. In the riot example, some consequentialists may argue that because wrongful conviction is unjust, it is ultimately impermissible (Murtagh, n.d.). Much of the complexity of corporal punishment in Singapore lays within its deterrent capacity and the tangible benefits of deterrence on economic development and security. Caning is often associated with deterrence, especially in the context of Singapore. When defending the Vandalism Act, which mandates caning for convicted males, founding father of modern Singapore Lee Kuan Yew argued that a criminal will lose enthusiasm for his crimes knowing that he will be caned, because "there is little glory attached to the rather humiliating experience of having to be caned"3l. If our victim views punishment as a tool for deterring crime, consequentialist ethics of punishment would certainly shape their decision, likely in the direction of caning. But at what point is deterrence no longer required? At what physical, mental, or emotional cost?

\section{COLONIAL CONTEXTS OF CORPORAL PUNISHMENT: DETERRENCE, HUMANITARIANISM, AND MODERNIZATION}

The desired deterrent effect of corporal punishment can be clearly seen in colonial accounts of discipline, punishment, and the "other" body. Colonization is essential to our discussion of Singapore, as the city-state was under various forms of British control from 1819 to 1963, excluding a three year period during the Second World War in which Japan retained control of the island. Caning as a form of punishment was brought to Singapore

\footnotetext{
${ }^{30}$ William. n.d Haines, "Consequentialism Epistemic | Internet Encyclopedia of Philosophy," diakses 10 November 2018, https://iep.utm.edu/epis-con/.

${ }^{31}$ Jothie Rajah, "Punishing Bodies, Securing the Nation: How Rule of Law Can Legitimate the Urbane Authoritarian State," Law $\sim$ Social Inquiry 36, no. 4 (ed 2011): 945-70, https://doi.org/10.1111/j.17474469.2011.01257.x.
} 
by the British ${ }^{32}$. Additionally, national civic education programs in primary and secondary school seek to form a national identity in light of Singapore's colonial history; therefore, colonial history is a factor in our victim's decision-making, albeit a superficial influence ${ }^{33}$. In order to better understand the moral complexity of caning in Singapore as a human rights violation, we must explore the relationship between colonization and corporal punishment.

Exploring corporal punishment in the colonial context suggests linkages between humanitarian ideologies, colonial corporeality, violence, governmental strategy, and codifying often racialized difference ${ }^{34}$. In Nigeria, despite scandals and humanitarian outrage over the use of flogging, flogging was viewed as a necessary punishment that was suitable only to the violence of the "native" people; a matching barbarity ${ }^{35}$. The perspective that violent punitive measures were suitable for native populations because of their purported inherent barbarity created a paradox in colonial efforts, insofar as their mission to "civilize" was dependent upon the use of punitive measures they regarded as harsh and uncivilized ${ }^{36}$. Similarly, claims of respect for traditional culture buttress the use of flogging in colonial settings. The necessity of flogging was solidified in that it was viewed as not only the most suitable punishment for the native people, but also the most powerful deterrent given its roots in "indigenous systems of justice" 37 .

The interaction of corporal punishment and colonization produced a climate in which "human" could be redefined through strategies of power and control ${ }^{38}$. The efficacy of such a plan is reflected in the use of dehumanization as a form of exclusion. Reconstructing humanity can involve the creation of categories of difference-such as that which existing in Nigeria, in which flogging laws and practices differed between men and women, as well as Muslim and non-Muslim persons-which reinforces the linkages between power, punishment, and human rights ${ }^{39}$. Punishment is legitimated on the basis that different groups require different degrees of punishment, which establishes a sense of humanitarian superiority, as was the case with flogging in Nigeria ${ }^{40}$. In Singapore, too, corporal punishment is justified by variation; only medically fit males ages 16-50 can be caned $^{41}$.

\footnotetext{
32 World Corporal Punishment Research, “About this website," diakses 2 November 2018, https://www.corpun.com/expl.html.

33 Adler, "Educating Citizens: A Cross-Cultural Conversation."

${ }^{34}$ Rao dkk., Discipline and the Other Body.

35 Pierce, Punishment and the Political Body, 193.

${ }^{36}$ Pierce, 193-96.

37 Pierce, 195.

${ }^{38}$ Rao dkk., Discipline and the Other Body.

${ }^{39}$ Pierce, Punishment and the Political Body.

${ }^{40}$ Pierce.

41 "United Nations Human Rights Office of the High Commissioner: Convention against Torture and Other Cruel, Inhuman or Degrading Treatment or Punishment."
} 
Colonial histories can also illuminate the influence of modernization on perceptions of punishment and torture. In a case study of torture in nineteenth century India, Anupama Rao suggests that torture becomes problematic when forms of subjectivation and embodiment are labelled "modern" in the context of a change in conceptions of physical vulnerability and personhood ${ }^{42}$. Changing perceptions of the body accompany changing perceptions of what it means to be human, and modernization paralleled the growing contradictory nature of colonization as a civilizing operation buttressed by very "uncivilized" forms of punishment. The linkages between modernization, colonization, and the rise of human rights in the West reinforce conceptions of torture and excessive punishment as problematic and the complicated relationship between punishment and human rights ${ }^{43}$.

Underlying many of the simultaneously colonial and humanitarian arguments of corporal punishment is a concept of traditional culture that ought to be respected. A popular excuse for humanitarian critics of flogging in Nigeria was that the practice was a colonial appropriation of tradition, an attempt to respect the native culture during the process of civilization ${ }^{44}$. Similarly, such "respect" was compounded by the claim that the maintenance of practices such as flogging were a part of the transition into civilization, the ideal end of which would be something akin to British civilization ${ }^{45}$. In fact, the use of traditional culture as an excuse for violations of human rights is not a thing of the past; it has been present in the fight for land rights in Hong Kong and the rights of domestic violence victims in Hawaii ${ }^{46}$. It is important to elaborate a conception of culture as a repertoire of ideas and practices that are constantly changing, contradicting, and impacted by the adoption of new practices and institutions among members of a culture ${ }^{47}$. This conception of culture is essential in understanding that culture or "tradition" is not inherently incompatible with change or the adoption of new or different values; rather, it is quite conducive to morphing to include these components on its own terms. Much like Nigeria, traditional culture claims are very present in the dilemma of caning in Singapore. The Asian values debate in part maintains that traditional cultural values such as Confucianist-rooted shame and community responsibility render Western human rights frameworks inapplicable ${ }^{48}$.

The complex relationship between colonization and corporal punishment has produced several ideas that are applicable to the case of Singapore, and rather critical in

\footnotetext{
${ }^{42}$ Discipline and the Other Body: Correction, Corporeality, Colonialism (London: Duke University Press, 2006), https://www.jstor.org/stable/j.ctvllsn6nq.

${ }^{43}$ Rao dkk., Discipline and the Other Body.

${ }^{44}$ Pierce, Punishment and the Political Body.

${ }^{45}$ Pierce.

${ }^{46}$ Engle Merry, Human Rights and Gender Violence.

${ }^{47}$ Engle Merry.

${ }^{48}$ Reynolds, "Intertwining Public Morality, Prosecutorial Discretion, and Punishment : Low Crime and Convictions in Singapore."
} 
understanding the complexity and controversy of corporal punishment. Deterrence is an essential value, purpose, and defense of caning in Singapore ${ }^{49}$. A particular understanding of what it means to be a human in the role of the citizen prescribes certain obligations and legitimates the use of caning as a punishment ${ }^{50}$. Given Singapore's civic education program, citizen-identity certainly shapes the decision of our victim ${ }^{51}$. Similarly, the use of caning solely as a punishment for men legitimates a claim to humanity in the practice. Modernization shapes much of the conflict surrounding caning; changing perceptions of rights and justice as belonging to the individual have altered perceptions of moral permissibility ${ }^{52}$. Traditional culture is a key feature of the Asian values debate that operates in defense of practices such as caning, yet by considering culture in terms of a repertoire of ideas and practices, we can push past the superficially restrictive claims of the traditional. While the greater complexities of colonization may not be clear to our victim, notions of citizenship, national identity, and colonial history will influence our victim's decision-making. Altogether, colonization's influence on both the cultivation and condemnation of modern corporal punishment is pronounced in Singapore, and significantly informs the moral dilemma of caning.

\section{THE SINGAPORE CASE: HOW DOES IT ALL ADD UP?}

\section{A. Criminal Justice in Singapore}

Caning is only one component of the intricate system that is Singaporean criminal justice. The central objectives of criminal justice in Singapore are retribution, deterrence, and incapacitation, yet recent years have shown a "quiet revolution" among Singaporean lawmakers that seeks to expand Singapore's already multifarious criminal justice system to include diversion programming $^{53}$. Criminal justice in Singapore is an elaborate system involving an impressive degree of variance. In addition to diversion programming, Singapore's criminal justice system includes farreaching prosecutorial discretion; the practice of compounding, by which criminal offenses are dealt with prior to and in lieu of conviction; and capital punishment ${ }^{54}$.

It is within this context that caning rests. By examining the complex system within which corporal punishment is situated, I argue that we can formulate a clearer understanding of the practice and the complexities that surround its existence; a necessary foundation from which to consider the "should" portion of our moral dilemma. National Singapore University Faculty of Law Kumaralingam Amirthalingam argues that criminal activity poses a threat to already vulnerable

\footnotetext{
${ }^{49}$ Reynolds.

${ }^{50}$ Pierce, Punishment and the Political Body; Reynolds, "Intertwining Public Morality, Prosecutorial Discretion, and Punishment : Low Crime and Convictions in Singapore."

${ }^{51}$ Adler, "Educating Citizens: A Cross-Cultural Conversation."

${ }^{52}$ Discipline and the Other Body.

53 Amirthalingam, "THE IMPORTANCE OF CRIMINAL LAW."

${ }^{54}$ Amirthalingam; Reynolds, "Intertwining Public Morality, Prosecutorial Discretion, and Punishment : Low Crime and Convictions in Singapore."
} 
developing states, and it is not uncommon for these "fledgling states" to place nation-building and security over the protection of individual rights and liberties ${ }^{55}$. The strict nature of Singaporean criminal justice in part grew out of a response to prolific gang criminality, racial riots, and insurgent activities that threatened economic development before Singapore rose to the status of one of Asia's four tiger economies ${ }^{56}$. The narrative of Singapore as a fragile state with limited resources, driven by "survival at all costs," bled into national identity when the state gained independence. While this angst lingers with older generations, younger generations argue that it hinders the imaginative capacity of the Singaporean people ${ }^{57}$. Our victim is situated in the middle of this generational conflict and is therefore no stranger to the narrative of a developing Singapore. While familiarity with the narrative of developing Singapore would suggest that the victim will report, a similar familiarity with the law-and-order state of today may lead to, at the very least, hesitance to report the crime.

That being said, the Singapore of today is no longer a developing state. According to the United Nations Human Development Index, which considers variables such as standard of living and education, Singapore is the ninth most developed country in the world ${ }^{58}$. I argue that, given the current levels of social, political, and economic development in Singapore, viewing criminal justice as a necessary mechanism of development is inaccurate. Amirthalingam suggests that Singapore ought to review the historical assumptions upon which its current system of criminal justice rests $^{59}$. Much like "traditional culture" arguments, viewing criminal justice as a static, immovable entity creates an obstacle that leaves moral inquiry and problem-solving stalled at the surface. I argue that criminal justice should also be viewed as a repertoire of norms, values, and philosophies that can be changed without losing its validity. For example, legal scholars in Singapore have acknowledged that "expanding regimes of criminalization and incarceration" do not address law and order, and that, in criminal justice, greater emphasis should be placed on the people impacted by crime-both offender and offended-rather than solely the crime itself ${ }^{60}$.

\section{B. Development \& "Good Government"}

The relationship between criminal justice and development explains, in part, the desire for deterrence in punishment that is so closely associated with caning. Given Singapore's history as a British colony, it is no surprise that development was both an obstacle and concern for the government; surely the sporadic growth experienced in the late twentieth century reinforced both concerns for and methods of development in the eyes of the state, and perhaps even those citizens who enjoy prosperity as well. Criminal justice enabled

\footnotetext{
55 Amirthalingam, "Criminal Justice and Diversionary Programmes in Singapore."

${ }^{56}$ Amirthalingam.

${ }^{57}$ Amirthalingam.

58 "Statistical Update 2018 | Human Development Reports."

${ }^{59}$ Amirthalingam, "THE IMPORTANCE OF CRIMINAL LAW."

${ }^{60}$ Amirthalingam, 535-99.
} 
Singapore to reinforce behaviors that were attractive not only to domestic security, but foreign investment as well ${ }^{61}$.

For example, in 1966, the Singaporean government enacted a law prohibiting vandalism, the minimum penalty for which is three strokes of the cane (Reynolds 2017). ${ }^{62}$ In addition to being considered a deterrent of foreign investment, vandalism became a cipher for opposition politics that would not be tolerated by the People's Action Party in the late twentieth century ${ }^{63}$. Insurgent activity is a threat to development, thus motivating the Singaporean state to crackdown on the behavior ${ }^{64}$. While some may find the law to be excessively harsh, I argue that it is reflective of what Mahbubani refers to as "good government" ${ }^{\prime 65}$. Used in the context of Mahbubani's argument that expecting human rights and democracy to precede economic development is impractical, "good government" refers to the efficacy of a government. Few can deny that Singapore's government was efficacious in terms of both development and criminal justice.

\section{The Asian Values Debate}

The current context of caning in Singapore is also heavily influenced by the Asian values debate. Although it is generally referred to as an event of the nineties, the Asian values debate is an ongoing contemplation of the universality of inherently "Asian" values, such as shame and community responsibility, as well as their compatibility with inherently "Western" values, such as democracy. The Asian values debate was notably adopted by Lee Kuan Yew, the founding father of modern Singapore, yet it is pervasive in any consideration of human rights in the context of Asia. In addition to claims of incompatibility with Western values, including those embedded in human rights frameworks, proponents of the Asian values debate have also promoted the idea that Confucian ideals of shame and community responsibility make the citizens of Singapore particularly sensitive to penalties such as caning, which involve a great deal of shame ${ }^{66}$. This is no coincidence; the unification of Singaporean society on the basis of Confucian values such as shame was an intentional move on behalf of Prime Minister Lee.

While some have argued that the Asian values debate was a response to Western proselytization and social and moral disorder, others argue that the debate was a neocolonial infantilization of the citizenry ${ }^{67}$. Certainly, it was used in both ways during the politicized Fay conviction in 1994. In response to this argument of incompatibility,

\footnotetext{
${ }^{61}$ Reynolds, "Intertwining Public Morality, Prosecutorial Discretion, and Punishment : Low Crime and Convictions in Singapore."

${ }^{62}$ Ironically, this is the law that Michael Fay was charged and convicted under (Rajah 2011).

${ }^{63}$ Rajah, "Punishing Bodies, Securing the Nation."

${ }^{64}$ Amirthalingam, "Criminal Justice and Diversionary Programmes in Singapore."

${ }^{65}$ Mahbubani, "The Case against the West," 45.

${ }^{66}$ Reynolds, "Intertwining Public Morality, Prosecutorial Discretion, and Punishment : Low Crime and Convictions in Singapore."

${ }^{67}$ Mahbubani, Can Asians Think?; Rajah, "Punishing Bodies, Securing the Nation."
} 
scholars such as Wm. Theodore de Bary have embarked on projects to explore the universality of these "Asian values," and, to an extent, their likeness to Western human rights values ${ }^{68}$. De Bary's project has shown that virtues referred to as "Asian values," such as compassion, are multiplex, existing in various spatio-temporal contexts with somewhat different but equally valid meanings ${ }^{69}$. This is supported by cross-cultural studies, such as Adler and Moi's work on citizenship, in which Singaporean and American preservice teachers equally emphasized compassion, respect, and empathy as a fundamental part of being a good citizen ${ }^{70}$. The Asian values debate bears importance in the influence it has had on transnational debates of the ethics of corporal punishment; even so, I argue that de Bary's concept of multiplex values and universality offers an essential insight into the complex, transnational existence and movement of virtue. It is through this understanding of values that we will explore the next phase: our dilemma.

\section{SPARE THE ROD, SPOIL THE SOCIETY?}

For the sake of convenience, I will repeat the dilemma here:

A crime was committed against you - a home burglary-with ample evidence to press charges against the offender, your neighbors' sixteen year-old son. The crime has impacted your security, your finances, and greatly inconvenienced you. Under Singaporean criminal law, men convicted of crimes and deemed of good health will endure a mandatory caning in addition to any prison sentence. The minimum required punishment for robbery is twelve strokes of the cane. Should you report the crime, given the great impact it has had on your life and security? Or, knowing punishment will result in the boy's physical and mental traumatization, should you avoid reporting the crime?

In this scenario, I will explore two potential outcomes. First, applying a scalar expectable consequentialist ethical framework, I argue that you should report the crime. Scalar expectable consequentialism is a combination of two forms of consequentialism: (1) plain scalar consequentialism, which argues that of any two options one may choose from in a given moment, one is superior to the extent that the overall consequences it will result in are superior; and (2) expectable consequentialism, which assumes that the morally correct [intentional] action is that with the greatest reasonably expectable consequences (Haines, n.d.). I use this framework of consequentialism as a result of the unpredictability of wider societal consequences, especially in relation to crime, as well as the binary nature of the dilemma.

Scalar expectable consequentialism assumes that you are faced with two options: you will either report the crime or not report the crime. By nature, consequentialism is

\footnotetext{
${ }^{68}$ Bary, NOBILITY AND CIVILITY.

${ }^{69}$ Bary.

70 Adler, "Educating Citizens: A Cross-Cultural Conversation."
} 
concerned with the overall effects of an action or decision ${ }^{71}$. For simplicity, we will begin with the immediate ramifications of your decision. Regardless of your decision, you have endured some sort of moral injury: your security, finances, and time have been impacted by the crime. There is no definite time frame within which you may return to the comfort of your existence before the crime, and such a return is by no means guaranteed. In contrast, reporting the crime could give you a sense of security, knowing that the offender is no longer near you. Furthermore, you may believe that caning will deter the boy from stealing again. That being said, caning is an excruciatingly painful experience. The experience may be dehumanizing, and will impact the boy's life for an indefinite period of time.

On a broader scale, it is possible that the unpunished boy could burglarize again. If the home is yours, you will be retraumatized. If it is another person, yet another person will be traumatized. Caning could bring shame to the boy, which would operate as another form of deterrence; however, shame could also be brought upon his family, who will have to support him in his trauma. Taken together, the potential consequences beg the question: will you spare the rod?

Attempting to weigh the consequences of each choice is indeed a laborious challenge. Even so, scalar expectable consequentialism suggests that you would report the crime. Despite the trauma it may cause the boy, you can reasonably expect that he will burglarize again. Regardless of whether or not he is punished, you have and will continue to feel insecure. The threat posed by his proximity to your residence could result in retraumatization. If all consequences are weighted equally, the boy's trauma and the potential shame born by his family do not equate to the offense that has occurred against you, the potential for recurrence and retraumatization, or the potential for others to be burglarized.

The second moral framework that I will apply is an agent-based accounts of virtue ethics. Agent-based virtue ethics are contingent upon an evaluation of the inner lives of those agents who perform an act being evaluated in ethical terms ${ }^{72}$. Through this framework, in which the virtue of focus is compassion, I argue that you will not report the crime.

To be clear, I would like to delineate virtue ethics from deontological ethics, such that I will not be pursuing or offering lawfulness as a virtue due to its proximity to the duties of citizenship. It is also worth noting that I have chosen compassion as a result of both de Bary's exploration of the virtue, such that it cannot be easily refuted by the Asian values debate, and for its presence in Singaporean preservice teachers' conceptions of a good citizen ${ }^{73}$. Compassion, which can be regarded as a concern or pity for the misfortune and suffering of others, is driven in this scenario by the immense pain and suffering to be

\footnotetext{
${ }^{71}$ Haines, "Consequentialism Epistemic | Internet Encyclopedia of Philosophy."

${ }^{72}$ Nafsika Athanassoulis, "Virtue Ethics," Internet Encyclopedia of Philosophy (blog), diakses 30 Oktober 2018, https://iep.utm.edu/virtue/.

${ }^{73}$ Adler, "Educating Citizens: A Cross-Cultural Conversation."
} 
endured by the boy if he is caned. I have already reviewed in significant detail the pain and dehumanization involved in caning; two factors which, despite their qualitative nature, should be taken seriously. Additionally, insofar as consequences can be considered in a virtue-based ethical evaluation, the shame brought upon both the boy and his family could lead to ostracism or other forms of suffering. Within this moral framework, you-the agent-seek to embody compassion. In order for your actions to be morally responsible or "right," you must embody compassion in the process of your decision-making; this will lead to a compassionate decision, which elects to spare the boy from his suffering ${ }^{74}$.

\section{CONCLUSION}

Caning in Singapore is not a normatively black and white issue. Exploring the dilemma in domestic and transnational contexts reveals the complicated history of corporal punishment; its ambiguous position in international and domestic law, the relationship between criminal justice and punishment, and the use of corporal punishment and torture as a necessary and humane practice by colonial powers. I argue that exploring our dilemma, which has the practice of caning at its heart, from multiple ethical perspectives reveals the complicated history and impacts of caning. In a modern context, this complexity places society and the individual at odds while challenging the universalityor arguments against universality - of certain values. While a consequentialist evaluation may suggest that it is more beneficial to report the crime, a virtue-based evaluation prizing compassion suggests foregoing the report and sparing the offender from tremendous pain and suffering.

It is possible that further exploration would lead to different results. Perhaps a deontological perspective would suggest a commitment to the duties of citizenship, which include lawfulness. Perhaps these duties would conflict. It is certain that changing elements of the dilemma and evaluation would result in further variation and the highlighting of greater complexities. For example, if the crime you were reporting was a crime of bodily harm, such as rape or murder, you may be far more likely to report the crime and view caning as a proportional, justifiable punishment. Similarly, changing the age of the offender would result in significant changes in perspective; it seems much easier to pity a child than a middle-aged man. A change in citizenship would change the actors involved, as was evident in the caning of Michael Fay. If the offender was a family member or a loved one, you may be much less likely to report them. The alterations and complexities are endless, highlighting the relentless complexity of caning as a moral ambiguity.

Of course, none of this complexity is simplified by the definitions put forth by international society. The delineation between lawful sanctions and torture seems blurred

\footnotetext{
${ }^{74}$ Athanassoulis, "Virtue Ethics."
} 
and is clearly colored by the issue of sovereignty. Following the path of the legal scholars I have included in this paper, I may argue, from a point of reflection, that Singapore reevaluate corporal punishment policies in the context of the development and prosperity it now enjoys. To argue that Singapore is still developing is to ignore the struggles that are faced by developing countries, including those that the state of Singapore has faced in its past. The reality of such a reflection and consideration is unclear to me; however, without such reflection, I do argue that the moral complexity of caning will only continue to grow, and not without implications for the health of the people subject to such a system of criminal justice.

\section{ACKNOWLEDGMENT}

This student paper would not have been possible without the support and guidance of Dr. Katherine Tegtmeyer Pak, who has always encouraged me to look beyond the surface of a question and into complexity. Thoughtful feedback provided by classmates and participants in Dr. Tegtmeyer Pak's seminar carried this paper from its initial inception to the final draft. Many thanks also to Dorinda Stryker for patiently correcting written mistakes along the way, and Pak Hery for encouraging me to share the final result of this thought exercise.

\section{COMPETING INTEREST}

None

\section{REFERENCES}

Adler, S. A., \& Moi, K. E. (2011). Educating Citizens: A Cross-Cultural Conversation. Journal of International Social Studies, 1(2), 2-20.

Amirthalingam, K. (2013). Criminal Justice and Diversionary Programs in Singapore. Criminal Law Forum, 24, 527-559. https://search.proquest.com/docview/\%0A1992037536?accountid=351 \%0A

Amirthalingam, K. (2017). The Importance of Criminal Law. Singapore Journal of Legal Studies, 318-328. https://search.proquest.com/docview/1461628691?accountid=351

Athanassoulis, N. (n.d.). Virtue Ethics. The Internet Encyclopedia of Philosophy. Retrieved October 30, 2018, from https://iep.utm.edu/virtue/

Bary, W. T. de. (2004). Nobility and Civility. Harvard University Press.

Chan, W.-C. (2013). Family Conferencing for Juvenile Offenders: A Singaporean Case Study in Restorative Justice. Asian Journal of Criminology, 8(1), 1-23. https://doi.org/10.1007/s11417-011-9122-y

Engle Merry, S. (2006). Human Rights \& Gender Violence. University of Chicago Press.

Haines, W. (n.d.). Consequentialism. The Internet Encyclopedia of Philosophy. Retrieved November 10, 2018, from https://iep.utm.edu/conseque/

Lum, S. (2015). Caning of Prisoners is Constitutional, Court of Appeal Rules. The Straits Times. 
https://search-proquest-

com.ezproxy.stolaf.edu/docview/1660636165\%0A?accountid=351\%0A

Mahbubani, K. (1998). Can Asians Think? Time Books International.

Morris, H. (1968). Persons and Punishment. The Monist, 52, 641-654.

Murtagh, K. (n.d.). Punishment. The Internet Encyclopedia of Philosophy. Retrieved October 30, 2018, from https://www.iep.utm.edu/punishme/

Nations, U. (2018a). Human Development Indices and Indicators. In 2018 Statistical Update. New York: United Nations Development Programme. http://hdr.undp.org/en/content/\%0Ahuman-development-indices-indicators-2018statistical-update $\% 0 \mathrm{~A}$

Nations, U. (2018b). United Nations Human Rights Office of the High Commissioner: Convention against Torture and Other Cruel, Inhuman or Degrading Treatment or Punishment. https://www.ohchr.org/en/professionalinterest/pages/cat.aspx

Nations, U. (2018c). Universal Declaration of Human Rights. http://www.un.org/en/universaldeclaration-human-rights/

Pierce, S. (2006). Flogging in Northern Nigeria. In In Discipline and the Other Body (pp. 186214).

Pierce, S., \& Rao, A. (2006). Discipline and the Other Body: Correction, Corporeality, Colonialism. Duke University Press.

Rajah, J. (2011). Punishing Bodies, Securing the Nation: How Rule of Law Can Legitimate the Urbane Authoritarian State. Law \& Social Inquiry 36, No. 4 (Fall).

Rao, A. (2006). Torture in Colonial India (P. Steven Rao \& Anupama (Eds.); In Discipl). Duke University Press.

Research, W. C. P. (n.d.). Judicial Caning in Singapore, Malaysia and Brunei. World Corporal Punishment Research. Retrieved November 2, 2018, from https://www.corpun.com/singfeat.htm Æhistory

Reynolds, Z. (2017). Intertwining public morality prosecutorial discretion and punishment: Low crime and convictions in Singapore. International Immersion Program Papers.

http://chicagounbound.uchicago.edu/international_immersion_program_papers/61

Ter Haar, G. (2003). Rats, Cockroaches, and People like Us. In J. Runzo, N. M. Martin, \& A. Sharma (Eds.), In Human Rights and Responsibilities in the World Religions. Oxford: Oneworld.

Watch, H. R. (2018). Singapore. Human Rights Watch. https://www.hrw.org/world\%0Areport2018/country-chapters/singapore $\$ \% 0 \mathrm{~A}$

Westacott, E. (n.d.). Moral Relativism. The Internet Encyclopedia of Philosophy. https://www.iep.utm.edu/moral-re/ 